\title{
DOBROCZYNNOŚĆ W IMPERIUM ROSYJSKIM NA PRZYKLADZIE KATOLICKICH STOWARZYSZEŃ W DIECEZJI TYRASPOLSKIEJ (SARATOWSKIEJ)
}

Dobroczynnością nazywamy wszelkiego rodzaju pomoc wobec grup osób i pojedynczych jednostek świadczoną ze strony Kościoła, organizacji społecznych i organów państwowych czy też osób prywatnych. Różne są motywy tego działania: uczucia religijne, solidaryzm społeczny, współczucie itd. Kościelna dobroczynność jest nakierowana na pomoc i wsparcie potrzebujących ${ }^{1}$.

Po raz pierwszy w Rosji zwrócił uwagę na dobroczynność jako na działalność niezbędną w kraju i dlatego wymagającą reglamentacji, car Piotr I. W czasie swoich rządów wydał on 320 ukazów skierowanych na walkę z ubóstwem. Pragnął osoby potrzebujące umieścić w zakładach pomocy a symulantów zsyłał na Syberię. Dla kalek zdolnych do pracy tworzył nowe miejsca pracy ${ }^{2}$. Działania te były kontynuowane przez jego następców. Wzorowanie się na działaniach państwowych dawało najlepsze szansy na powodzenie akcji katolickich.

Z inicjatywy cara Aleksandra I w 1802 roku powstał w Petersburgu medyczno -filantropijny komitet który w 1816 r. został nazwany Imperatorskim Towarzystwem Miłości Bliźniego. Szeroko był zakrojony zakres działań stowarzyszenia: pomoc lekarska dla biednych, pomoc w zatrudnianiu i opieka nad starcami i kalekami, tymczasowa pomoc finansowa itd. $\mathrm{Z}$ czasem działania tego towarzystwa przyniosły obfite owoce ${ }^{3}$. Dla nas istotną informacją są cele stawiane przez stowarzyszenie ponieważ powstające $\mathrm{w}$ późniejszym czasie katolickie stowarzyszenia

* Bohdan Kukharenko - dr historii.

${ }^{1}$ П. Романов, С. Романов, Благотворительность, в: Католическая энциклопедия, Москва 2002, т. 1 , s. 605

${ }^{2}$ Петр I, w: Благотворители и меценаты прошлого и настоящего. Словарь справочник oт A до Я, авторы - составители: М. Л. Макальская, Н. Н. Бобровская, Москва 2003, s. 119120.

${ }^{3}$ A. R. Sokołow, Rosyjska dobroczynność wzwierciadle historii. Przedrewolucyjna historiografia działalności dobroczynnej i dobroczynnych instytucji, Sankt-Petersburg-Warszawa 2002, s. 62-63; Человеколюбивое общество, w: Благотворители и меценаты, s. 225. 
wzorowały się często na statucie tego stowarzyszenia, tylko ograniczając zakres działania do swoich współwyznawców. Był to skuteczny sposób na zarejestrowanie stowarzyszenia przez władze lokalne i ministerstwa, bo autorytet cara chronił przed zbytnią podejrzliwością urzędników.

Doceniając wagę dobroczynności w życiu społeczeństwa, car Mikołaj I powołał przy swojej osobistej kancelarii IV oddzielenie. W zadania tego oddzielenia wchodziło nadzorowanie stowarzyszeń dobroczynnych i filantropijnych w całym imperium. ${ }^{4}$

Katolickie towarzystwa dobroczynności zakładane na początku XIX wieku w imperium rosyjskim były po części odpowiedzią na rządową kasatę instytucji charytatywnych. Powstawały przy współudziale znanych osobistości duchownych tak i świeckich. Regulamin tych organizacji oparto na zasadach moralności chrześcijańskiej ${ }^{5}$.

Kościół katolicki był poddany opiece Departamentu Wyznań Obcych i dlatego każde działanie charytatywne było poddane specjalnej kontroli. Podejrzewano takie działania niekiedy jak środek prowadzący do porzucenia wyznania panującego $^{6}$. Takie ograniczenia w pierwszej połowie XIX w. dobroczynności katolickiej powodowało zawężenie jej do terenu parafii i organizacji przy niej istniejących. Jednorazowe akcje, szczególnie prowadzone z innymi organizacjami, w postaci loterii, wieczorów tanecznych i zbiórek pieniędzy, również miały miejsce. Nie odmawiano przyjęcia ofiar od osób prywatnych ${ }^{7}$.

Pierwsze stowarzyszenie charytatywne $\mathrm{w}$ diecezji tyraspolskiej powstało w Odessie w 1846 roku. Car zatwierdził prośbę Niemców o powstanie bezwyznaniowego towarzystwa dobroczynności. Zasady jego działania były omówione szczegółowo w regulaminie który można uznać za wzorowy dla imperium rosyjskiego. Ofiary powinne były być przekazywane do banku i dysponowano tylko procentami z kapitału. Członkowie mieli się zobowiązać do corocznych ofiar na rzecz towarzystwa, nadto pracowali bez wynagrodzenia, prowadzili dokumentację i mieli obowiązek rozliczenia się z działalności rocznej przed Ministrem Spraw Wewnętrznych. Ofiary mogły być wydawane jednorazowo lub w ratach ${ }^{8}$.

Sytuacja zmieniła się w drugiej połowie XIX w. Zaczęły się formować struktury stowarzyszeń dobroczynnych, które swój ostateczny kształt przybrały w latach 90. XIX wieku. Już w latach 1830-1840 w Odessie powstał katolicki komitet dobroczynny. W latach 60 . XIX w. powstają stowarzyszenia pomocy biednym wyznania rzymskokatolickiego zarejestrowane jednak w późniejszych latach. Budżet tych stowarzyszeń powstawał w drodze uiszczenia składek członkowskich, darowizn, jednorazowych akcji oraz zapisów w testamentach ${ }^{9}$.

W pierwszych dziesięcioleciach XIX w. przy powstaniu niemieckich organi-

${ }^{4}$ М. Геллер, История российской империи в трёх томах, Москва 1997, t. 3, s. 20.

${ }^{5}$ K. Kuźmiak, Dobroczynności towarzystwa, w: Encyklopedia Katolicka, t. 3, red. R. Łukaszyk, Lublin 1979, kol. 1389-1390.

${ }^{6}$ П. Романов, С. Романов, Благотворительность, s. 607.

${ }^{7}$ Tamże, s. 608.

${ }^{8}$ Полное Собрание Законов российской империи, собр 2, т 21, отд. 2, № 20340.

9.П. Романов, С. Романов, Благотворительность, s. 608. 
zacji i stowarzyszeń decydującym czynnikiem była wspólnie wyznawana wiara ${ }^{10}$. $Z$ biegiem czasu, diaspora niemiecka większy akcent położyła na wspólne pochodzenie i większość organizacji powstawało bez zaznaczenia swojej konfesji.

W roku 1908 w Odessie powstało rzymsko-katolickie stowarzyszenie imienia Św. Klemensa. Inicjatorem jego powstania był ówczesny biskup saratowski A. Kessler. Wśród założycieli byli miejscowi duchowni I. Wolf i A. Keller oraz świeccy: A. Tauberg, I. Frank i J. Gerhard ${ }^{11}$. Towarzystwo jednak nie ograniczyło swej działalności do Odessy i działało na terenie całej diecezji ${ }^{12}$. Należy zwrócić uwagę na bardzo nietypowy cel tego religijnego stowarzyszenia. W swoim regulaminie deklarowali ,zdecydowane przeciwstawienie socjalistycznym i innym antypaństwowym łże naukom"13.

Członkiem stowarzyszenia mogli być wyłącznie obywatele rosyjscy, a ze względu na swoją konfesyjną orientację, duży procent przypadał na duchowieństwo. Ono również pełniło większość funkcji w zarządzie ${ }^{14}$.

Celem stawianym sobie przez założycieli było zorganizowanie życia katolików i ich rozwój duchowy. Miało się to odbywać za pomocą wydawania gazet, książek i czasopism. Przewidywano otwarcie bibliotek, wygłaszanie publicznych lekcji, wystawianie sztuk teatralnych i organizowanie wieczorów muzycznych.

Tak silny wpływ duchownych na stowarzyszenie wywoływał u wielu osób obawy o jego przyszłość. Wierni oczekiwali rozwiązań, które polepszą ich los w aspektach kulturowych, gospodarczych i religijnych. Szczególnie tych, które są rzeczywiście ważne dla nich, a nie dla kleru ${ }^{15}$. Nie może to dziwić jeżeli zobaczymy jaki procent stanowili księża. I tak, w 1914 roku na 325 członków aż 42 to duchowni, co stanowiło prawie $13 \%{ }^{16}$. W połączeniu z ich decydującym głosem w zarządzie mogło to budzić obawy w pewnych katolickich kręgach.

Aby stowarzyszenie mogło realizować swoje założenia niezbędna była drukarnia. Dlatego z Saratowa do Odessy sprowadzono typografię gazety „Deutsche Rundschau", która ukazywała się od października 1908 r. Wszystko co ukazywało się w typografii było rozprowadzane wśród katolików niemieckich diecezji tyraspolskiej. Liczba jego członków i prenumeratorów stale rosła co było wynikiem działań propagandowych $\mathrm{w}$ terenie: księży, przedstawicieli miejscowej administracji, kościelnych aktywistów ${ }^{17}$.

W 1914 r. stowarzyszenie podzieliło los innych niemieckich organizacji. W sierpniu tego roku władze podjęły decyzję o likwidacji stowarzyszenia św. Klemensa. Zarzucano mu szerzenie pangermanizmu wśród rosyjskich Niemców, przez spajanie ich więzami katolicyzmu i języka. Polecono również likwidację

\footnotetext{
10 Э. Г. Плесская-Зебольд, Одесские немцы 1803-1920, Одесса 1999, s.317.

${ }^{11}$ Государственный Архив Одесской Области ф. 2, оп. 7, д. 253, л. 1.

${ }^{12}$ Tamże, л. 2.

${ }^{13}$ Tamże.

${ }^{14}$ Tamże, л. 2 об.

${ }^{15}$ Плесская-Зебольд, Одесские немиы, s. 340.

${ }^{16}$ ГАОО ф. 2, оп. 7, д. 253, л. 25-27.

${ }^{17}$ Плесская-Зебольд, Одесские немиы, s.341.
} 
typografii ${ }^{18}$. Próbując odwołać się od tej decyzji, zarząd skierował do gubernatora list w którym wymienił dowody swojej lojalności państwowej. Wskazał, że towarzystwo św. Klemensa zrzesza tylko obywateli rosyjskich, nadto zebrało pokaźną sumę pieniędzy dla rannych żołnierzy i dla szpitali ${ }^{19}$. Decyzję o likwidacji władze jednak utrzymały w mocy i 19 IX/02 X 1914 na walnym zebraniu powzięto uchwałę o likwidacji. Majątek który pozostał przekazano na rzecz seminarium w Saratowie ${ }^{20}$.

Inną formą zrzeszania katolików w Odessie było Katolickie Południowo-Rosyjskie Niemieckie Stowarzyszenie Oświatowe. Wydaje się rzeczą niemożliwą zrzeszenie wszystkich katolików Niemców w ramach jednej organizacji. Dyskusja toczona na łamach „Deutsche Rundschau” w marcu 1908 r. była bodźcem do głębokich przemyśleń nad potrzebami katolików Niemców. Ciężkie życie kolonistów i ich bojaźń o własny dorobek w porewolucyjne lata stworzył wspólny fundament do porozumienia. Polepszenie materialnego statusu widziano w podniesieniu poziomu szkolnictwa, często bardzo słabego. Wzorowano się na przykładach Niemiec i diaspory w Stanach Zjednoczonych ${ }^{21}$.

Zebranie katolików z południowych guberni imperium miało miejsce 16 i 17 kwietnia 1908 r. w szkole przy kościele. Od razu położono akcent na przezwyciężenie podziału katolików na kler i świeckich. Otwartość nowego stowarzyszenia, które nazwano Południowo-Rosyjskim Niemieckim Stowarzyszeniem Oświatowym, na wszystkich Niemców katolików było kamieniem węgielnym ${ }^{22}$.

Dla gubernatora nie było trudną decyzją zarejestrowanie nowego stowarzyszenia. Myślą przewodnią było podniesienie poziomu życia, tak materialnego jak i duchowego, Niemców kolonistów. Stowarzyszenie stawiało za swój cel pomoc w nauce szkolnej dla dzieci narodowości niemieckiej, Chciało organizować biblioteki, nowe szkoły i kursy dla nauczycieli. Nadto planowano wygłaszanie lekcji i organizację koncertów oraz wydawanie czasopism i dzienników. Stowarzyszenie zakładało swój rozwój i omawiano kwestię powstania filiii ${ }^{23}$. Założycielami stowarzyszenia byli nauczyciele: G. Tauberg, I. Franc, kapitan J. Gerhard, ksiądz I. Wolf $i$ kolonista L. Reiher. Trzy osoby z wyżej wymienionych były również założycielami Stowarzyszenia św. Klemensa ${ }^{24}$.

Brak jakichkolwiek innych materiałów archiwalnych nie daje możliwości naświetlenia działalność towarzystwa. Jego krótkie istnienie, bo zlikwidowano je w 1915 roku, nie dało żadnych widocznych skutków działalności. Podobnie jak Stowarzyszenie św. Klemensa walczyło z szerzeniem się idei socjalistycznych co możemy stwierdzić na podstawie publikacji w „Deutsche Rundschau”25.

W 1907 r. powstało kobiece stowarzyszenie pomocy biednym Niemcom wy-

${ }^{18}$ ГАОО ф. 2, оп. 7, д. 253, л. 12.

${ }^{19}$ Плесская-Зебольд, Одесские немиы, s.341-342.

${ }^{20}$ ГАОО ф. 2, оп. 7, д. 253, л. 33.

${ }^{21}$ Mowa o rewolucji 1905 roku. Плесская-Зебольд, Одесские немиы, s.342-343.

${ }^{22}$ Tamże, s.343.

${ }^{23}$ ГАОО ф. 2, оп. 7, д. 245, л. 7 об.

${ }^{24}$ Tamże, л. 1 об.

${ }^{25}$ Плесская-Зебольд, Одесские немиы, s.343-344. 
znania katolickiego „Maria-Gilf”. Stowarzyszenie to zajmowało się pomocą sierotom, chorym i kalekom w znalezieniu pracy i przytułku. Biednym rodzinom udzielano zapomogi pieniężne ${ }^{26}$. Informacje o imprezach kulturalnych oraz swoich zebraniach stowarzyszenie publikowało na łamach gazety „Deutsche Rundschau", co stanowiło tradycję dla towarzystw niemieckich.

W Odessie działało jeszcze jedno katolickie stowarzyszenie - Niemieckie Towarzystwo Katolików Służących. Z przykrością należy stwierdzić, że brak jest jakichkolwiek informacji o nim w archiwach ${ }^{27}$. Znamy tylko fakt, że zorganizowanie takiego towarzystwa było możliwe tylko za zgodą władz zwierzchnich. Warunkiem było współbrzmienie celów towarzystwa z obowiązkami zawodowymi. Po 1906 roku Ministerstwo Spraw Wewnetrznych przekazało zatwierdzenie regulaminów tych towarzystw $\mathrm{w}$ ministerstwie gdzie pracowali petenci ${ }^{28}$.

W swoim testamencie biskup W. Lipski, który umarł 11/24 XII 1875 r., pozostawiony przez siebie majątek przeznaczył na różne cele. Na zorganizowanie przytułku dla okaleczonych katolików niezdolnych do pracy przekazał aż 10.000 rubli. Dom wybudowany dla nich za oszczędności na terenie należącym do kościoła przeznaczył na przytułek. Aby wykonać testament, Kolegium MSW skontaktowało się z miejscową władzą w celu uzyskania opinii na temat możliwości jego realizacji. Odesski gubernator obok zgody zastrzegał, aby przyjmować do przytułku tylko mężczyzn po przekroczeniu 60 lat. Opiekunem miał być dziekan i co roku przedstawiać sprawozdanie z funkcjonowania przytułku gubernatorowi miasta $^{29}$. W 1877 r. przyjęto jednak do przytułku 4 kobiety, co było spowodowane większą liczbą potrzebujących pomocy kobiet, niż mężczyzn i ich bardziej skomplikowaną sytuacją życiową ${ }^{30}$.

Wolą biskupa W. Lipskiego, było powołanie do istnienia przytułku. Jednak wizje odesskiego proboszcza i władz państwowych, odnośnie jego funkcjonowania różniły się. Pieniądze były zdeponowane $\mathrm{w}$ banku, a finansowanie przytułku było możliwe wyłącznie z corocznych odsetek bankowych. Zamiast przewidywanych przez władze kościelne 20 osób, rząd po obliczeniu wydatków zezwolił na utrzymanie tylko 5 osób $^{31}$. Projekt regulaminu przytułku był bardzo szczegółowy i rygorystyczny. Miało to umożliwić jego rejestrację i zapobiec nieporozumieniom na przyszłośćc ${ }^{32}$.

Przy odesskim kościele Zaśnięcia Matki Bożej 16/29 V 1882 r. zarejestrowano dobroczynne parafialne stowarzyszenie. Za swój główny cel stowarzyszenie stawiało pomoc dla biednych katolików, których w Odessie było bardzo dużo. Pomoc ta zakładała tak opieke nad sierotami i osobami starszymi oraz pomoc pieniężną, pośrednictwo $\mathrm{w}$ znalezieniu pracy dla bezrobotnych. W przyszłości

${ }^{26}$ ГАОО ф . 2, оп. 7, д. 166, л. 1, 2.

${ }^{27}$ Плесская-Зебольд, Одесские немиьь, s. 344.

${ }^{28}$ Российский Государственный Иисторический Архив в Санкт - Петербурге ф. 821, оп. 125, д, 3029, л 29, 29 об.

${ }^{29}$ ГАОО ф . 2, оп. 7, д. 166, л. 20, 21, 22, 22 об., 23.

${ }^{30}$ Tamże, л. 30, 30 об., 31.

${ }^{31}$ Tamże, л. 48, 48 об.

${ }^{32}$ РГИА ф. 821, оп. 125, д, 2486, л 40-46об. 
zakładano powstanie jakiegoś zakładu gdzie młodzież mogłaby pobierać naukę rzemiosła usamodzielniając się w życiu. Stowarzyszeniu przewodniczył zawsze proboszcz kościoła a członkowie dzielili się na honorowych i stałych. Status członka zależał wyłącznie od sumy wnoszonej na cele stowarzyszenia. Cezurę stanowiła jednorazowa wpłata stu rubli. Zarząd składający się z dziewięciu osób był każdorocznie wybierany na nowo. Przewidywano prowadzenie spektakli, koncertów czy też loterii dla zasilenia kapitału stowarzyszenia. Liczono również na składki członkowskie i jednorazowe ofiary. W celu zabezpieczenia swego funkcjonowania $20 \%$ od zebranych sum stowarzyszenie przekazywało na swoje konto bankowe aby w przyszłości zakupić nieruchomości w Odessie ${ }^{33}$.

Towarzystwo prężnie działało i 23 II/8 III 1899 r. zwróciło się do gubernatora z prośbą o zgodę na otwarcie większego przytułku dla dzieci - na 60 osób. W tym czasie parafiia liczyła 30 tys. osób ${ }^{34}$. W roku 1904 doszło do zakupu nieruchomości w Odessie przez towarzystwo w celu urządzenia letnich kolonii gdzie miały przebywać dzieci z szkoły parafialnej3.

Niestety powstanie drugiej parafii w Odessie, pod wezwaniem św. Klemensa, nieco zahamowało działalność towarzystwa. Zrzeszająca w większości katolików narodowości polskiej parafia św. Klemensa, podzieliła katolików według narodowości ${ }^{36}$. Nie był to niestety odosobniony przypadek. Np. dobroczynne parafialne towarzystwo w Kiszyniowie w 1907 r. rozsyłało listy do wszystkich parafii w Besarabii i okolicznych powiatów guberni chersońskiej z propozycją wystarania się u władz państwowych zezwolenia na przyłączenie tych terenów do diecezji łucko-żytomierskiej ${ }^{37}$. Było to wynikiem działań katolików narodowości polskiej, którzy mając przewagę liczebną (na 19.825 katolików w guberni, 11.696 osób stanowili Polacy co wynosiło 59\%) pragnęli wykorzystać organizacje kościelne dla swoich interesów narodowych. Zostało to potępione tak przez gubernatora besarabskiego jak i biskupa tyraspolskiego ${ }^{38}$.

Stowarzyszenia pragnęły zjednoczyć katolików na podstawie interesów własnej społeczności. Znając reakcje władz na hasła nacjonalne z góry określały, że nie będą zajmowały się taką działalnością. Tylko w regulaminie jednego towarzystwa niemieckiego w Odessie dozwolone było omawianie politycznych kwestii $^{39}$.

Jeszcze do wybuchu pierwszej wojny światowej, w dniu 28 XII 1909/10 I 1910 roku, Minister Spraw Wewnętrznych w swoim okólniku zakazał rejestracji nowych stowarzyszeń, zrzeszających cudzoziemców i ich potomków. Istniejące dotychczas proponowano zamykać jako formujące w świadomości członków wąsko rozumiane narodowe interesy ${ }^{40}$.

33 Устав приходского благотворительного общества при римско-католической церкви в г. Одессе, w: ГАОО ф. 35, оп. 1, д. 22476, л. 15-18; РГИА ф. 821, оп. 125, д, 3025, л 53-56.

${ }^{34}$ ГАОО ф.2, оп. 1, д. 2618, л. $1,2$.

${ }^{35}$ ГАОО ф. 35, оп. 1, д. 22476, л. 6.

${ }^{36}$ РГИА ф. 821, оп. 128, д, 155, л 29-30.

${ }^{37}$ Tamże, оп. 125, д, 3029, л. 69-72 об.

${ }^{38}$ Tamże, л 69, 110-111 об.

${ }^{39}$ Плесская-Зебольд, Одесские немиьы, s. 327.

${ }^{40}$ ГАОО ф . 2, оп. 7, д. 101, л. 195. 
W innych częściach diecezji tyraspolskiej również powstawały stowarzyszenia choć w żadnym innym mieście nie dorównały one tym istniejącym w Odessie.

W Kerczu powstała inicjatywa powstania towarzystwa dobroczynności o czym zawiadamiał Minister Spraw Wewnętrznych w liście z 20 X 1887 r. Kercz-Jenikalski gubernator.

W Saratowie biskup A. Zerr w 1889 r. starał się o pozwolenie na przeprowadzenie zbiórki pieniężnej między katolikami w ciągu dwóch lat co miało umożliwić powstanie przytułku dla zubożałych parafian. Władza państwowa zawsze, kiedy to nie pociągało kosztów z jej strony a było wyłącznie społeczną inicjatywą wyrażało swoją zgodę ${ }^{41}$.

W Tyflis inicjatywa powstania towarzystwa pojawiła się w $1890 \mathrm{r}$. Władze jednak nie zgodziły się na otwarcie szpitala, jak zakładał komitet, a szkołę oddały pod zarząd Ministerstwa Oświaty ${ }^{42}$.

Inicjatywy organizowania nowych szkół i stowarzyszeń była ciągle żywa, aż do ostatnich dni rządów dynastii Romanowów. Odesski gubernator w liście z 04 II 1916 r. zwracał się do Departamentu Wyznań Obcych z zapytaniem w sprawie otwarcia przy przytułku dla biednych dziewcząt rzymskokatolickiego wyznania szkoły podstawowej. Przewodnicząca tego towarzystwa M. Drzewiecka prosiła o modyfikację dotychczasowego regulaminu w celu umożliwienia zrealizowania tego zamierzenia. Chociaż sama prośba była zbyteczna, prawo dozwalało na utworzenie prywatnych szkół bez zezwolenie ministerstwa już od kilku lat, niemniej pokazuje to żywotność podejmowanych wysiłków poszczególnych organizacji i ludzi ${ }^{43}$.

Większość placówek wyznaniowych było pozbawiono możliwości zorganizowania towarzystw dobroczynności przez dłuższy czas. Było to spowodowane szeregiem przyczyn. W wielu miastach wspólnoty były zbyt nieliczne a przede wszystkim biedne. Dopiero ich rozrost umożliwił na przełomie XIX-XX w. zorganizowanie jakichś form organizacji społeczno-religijnych. Często przeszkadzał w tym czynnik narodowy. Tymczasowy charakter przebywania wielu wyznawców, kupców, zesłańców, korpusu urzędniczego i oficerskiego nie dawał możliwości podjęcia jakichkolwiek długotrwałych działań społecznych.

Z kolei sytuacja taka nie istniała na wsi, gdzie była ulokowana większa część katolików diecezji. Tam sama wspólnota zobowiązywała się wspierać swoich członków i trudno oczekiwać inicjatyw powstania np. przytułków w koloniach.

Sama rejestracja towarzystw nie była rzeczą łatwą. Często organy państwowe same nie znały jak zakwalifikować te albo inne stowarzyszenia. Ukaz z $1906 \mathrm{r}$. wszystkie organizacje realizujące cele religijne oddał do rejestracji w Ministerstwie Spraw Wewnętrznych. Tam traktowano to pojęcie bardzo szeroko i każde stowarzyszenie dążące do polepszenia warunków życia i poziomu kultury swoich współwyznawców było rejestrowane. Senat jednak zadecydował o nieprawidłowości tej praktyki i zakazał takie działania od 11 II 1916r. Powoływane od tej

\footnotetext{
${ }^{41}$ РГИА ф. 821, оп. 125, д, 3025, л 141-143.

${ }^{42}$ Tamże, л 236,247,289.

${ }^{43}$ Tamże, оп. 128, д. 1632, л 3-4.
} 
pory towarzystwa miały być rejestrowane na podstawie ogólnych przepisów ${ }^{44}$.

Działania dobroczynne podejmowane pod koniec XIX wieku, miały charakter oddolnych inicjatyw i władze były zazwyczaj niedoinformowane o ilości istniejących stowarzyszeń i celach przez nich stawianych. Nie rozprzestrzeniano tej wiedzy w społeczeństwie i osoby pragnące wziąć udział w akcjach pomocy bliźniego również były pozbawione tych informacji ${ }^{45}$.

Należy zauważyć również negatywne skutki istnienia organizacji katolickich. W przytułku przy rzymskokatolickim kościele w Odessie w latach 1903-1911 pracowały siostry św. Józefa zaproszone tu z Moskwy. Praca ich była oceniana dobrze przez władze duchowne ale złamały one prawo rosyjskie, zabraniające działalności zakonów z zagranicy bez zgody władz państwowych. Z narodowości były to Polka, dwie Francuzki i jedna Serbka. Jedna pełniła obowiązki kucharki, jedna służącej i dwie uczyły dziewczęta ${ }^{46}$. Przytułek został założony 19 IX 1875 roku, dzięki darowiźnie szlachcica S. Mikulicza opiewającej na 87 tys. rubli. Procent $\mathrm{z}$ tych pieniędzy umożliwił funkcjonowanie przytułku. Przyjmowano wyłącznie rzymskich katolików bez względu na ich narodowość, przy zdecydowanej przewadze Polakó $w^{47}$. Niestety siostry jednak nie znały języka rosyjskiego co stanowiło istotną przeszkodę $\mathrm{w}$ pracy.

Podobnie było w przypadku funkcjonowania na terenie diecezji tyraspolskiej Zgromadzenia Sióstr Franciszkanek Rodziny Maryi. Szlachcianka Maria Drzewiecka pragnąca prowadzić życie zakonne za granica, została odwiedzona od tego zamiaru przez F. Dymman, przełożoną zgromadzenia z Warszawy. Za jej namową założyła ona 27 XII 1879 r. zakład dla biednych dziewcząt w Odessie ${ }^{48}$. Władze nie wiedziały, że pracują tam siostry z Warszawy gdyż nie wyrażono by na to zgody. Zakładano z góry, że stanowisko społeczne zajmowane przez tą szlachciankę będzie skutecznym zabezpieczeniem przed zainteresowaniem się zakładem przez policję ${ }^{49}$. Sama M. Drzewiecka zatajała swą przynależność zakonną przed niewtajemniczonymi.

W jej domku letniskowym powstał przytułek i szkoła dla 85 dziewcząt. Najbardziej zdolnym umożliwiano potem naukę w gimnazjum. Uczono polskiego, niemieckiego, francuskiego oraz różnych ręcznych robót. Finansowanie nauki odbywało się kosztem M. Drzewieckiej oraz dzięki ofiarom innych Polaków. Podobnie na Limanie Hadżibejskiem powstał przytułek dla dzieci katolików narodowości polskiej, a na Peresypie (czesść Odessy) szkoła dla biednych dzieci polskich robotników. Przy szkole Drzewieckiej była kaplica gdzie byli zapraszani księża również z innych miast. Oddanie sprawie polskiej było tak wielkie, że cały swój majątek M. Drzewiecka zapisała na rzecz Polskiego Towarzystwa Katolickiego. Dzieci były wychowywane w tradycji polskiej, nieprzyjaźnie do kultury rosyjskiej i Rosji w ogóle ${ }^{50}$.

${ }^{44}$ РГИА ф. 821, оп. 128, д. 1632, л 28, 28 об.

${ }^{45}$ Благотворительность, w: Благотворители и меценаты, s. 17.

${ }^{46}$ РГИА ф. 821, оп. 128, д, 182, л 123-124.

${ }^{47}$ Tamże, л 127, 127 об.

${ }^{48}$ Notatki siostry Teresy Helman, wstępem zaopatrzył ks. M. Wawrzyniec, Archiwum Główne Zgromadzenia Sióstr Franciszkanek Rodziny Marii w Warszawie, ARM F-f-8, s. 142-143.

${ }^{49}$ Tamże, s. 145.

${ }^{50}$ РГИА ф. 821, оп. 128, д, 182, л 136-138. 
Posiadłość M. Drzewieckiej, wynosiła około 2 hektarów i była położona blisko morskiego wybrzeża. Sąsiadowała jedynie z posiadłością państwa Wołodkowiczów, a pani Wołodkowicz była rodzoną siostrą M. Drzewieckiej. Było to pomocne w zachowaniu dyskrecji całego przedsięwzięcia. Nawet siostry nie znały do końca jak funkcjonował przytułek na zewnątrz bo ich przełożona załatwiała wszystkie sprawy sama. Za swoją działalność odpowiadała jedynie przed przełożoną w Warszawie ${ }^{51}$.

Podobnie w Jałcie powstał przytułek dla dzieci z woli księżnej Izabelli Gagarin. Zaofiarowała ona pomoc siostrom w Petersburgu by wywoziły chorowite dzieci do jej posiadłości w Jałcie na kurację. Majątek składał się z kilku domków $\mathrm{w}$ jednym z których urządzono kaplicę. Władze również nie wiedziały o tym, że zakonnice prowadzą tu sanatorium, podobnie o istnieniu tamtejszej kaplicy. Sanatorium było prowadzone przez siostry wzorowo, a katolicy mogli korzystać z kaplicy przy której mieszkał ks. Drzewulski, były wygnaniec polityczny. Aby nie ulec dekonspiracji przyjmowano tylko osoby znane i wtajemniczone narodowości polskiej a wyznania rzymskokatolickiego. Było to miejsce szczególnie lubiane przez duchowieństwo polskie.

Po śmierci księżny I. Gagarin przełożona domu w Jałcie Maria Olszewska przepisała ten dom na siebie bo zawiadywała nim przez długie lata a tym samym prawa Gagarinów uległy przedawnieniu. Zrobiła to w trosce o przyszłość zakładu: darowizna była zrobiona tylko ustnie i spadkobierca księżnej, jej syn i dworzanin wyznania prawosławnego, mógł odebrać to mienie aby nie narażać się carowi. Sądy w Jałcie i Symferopolu uznały jej roszczenia. Dopiero wtedy siostra mogła przekazać tą posiadłość na rzecz zakładu dla biednych rzymskokatolickiego wyznania w Petersburgu. Przed samą rewolucją majątek ten został sprzedany przez M. Drzewiecką ${ }^{52}$.

W latach pierwszej wojny światowej struktury Kościoła katolickiego okazywały pomoc uciekinierom i jeńcom wojennym. Działalność ta była bardzo różnorodna: kuchnie dla potrzebujących, kursy i szkoły dla dzieci, noclegownie itp ${ }^{53}$.

Wtedy również masowo otwierane były przytułki dla uciekinierów z Kraju Nadwiślańskiego. Istniały one tylko kilka lat, dlatego też trudno odtworzyć ich działalność. Przy tych przytułkach starano się zawsze otwierać szkoły z polskim językiem nauczania ${ }^{54}$. Było to jednak zjawisko tymczasowe i nie charakterystyczne dla diecezji tyraspolskiej.

Katolicy wchodzili również w inne towarzystwa dobroczynności, nie mające charakteru katolickiego. W Nikołajewie przy szpitalu dla marynarzy zorganizowane było w 1895 roku bractwo, którego członkami byli dwaj lekarze wyznania katolickiego ${ }^{55}$.

W latach pierwszej wojny światowej w celu opieki nad uchodźcami narodo-

${ }^{51}$ ARM F-f-3, s. 1-2.

${ }^{52}$ ARM F-f-8, s. 154-161.

${ }^{53}$ П. Романов, С. Романов, Благотворительность, s. 609.

${ }^{54}$ РГИА ф. 821, оп. 128, д, 1642, л 35, 38-38 об.

${ }_{55}$ Российский Государственный Архив Военно-Морского Флота в Санкт-Петербурге, ф. 920, оп. 4, д. 3, л. 7, 7 об. 
wości polskiej powstało w stolicy Polskie Towarzystwo Ofiarom Wojny (PTOW), które działało w całym kraju. Na Kaukazie miało ono jedenaście oddziałów. Ponadto w Tyflisie działały: Stowarzyszenie Dom Polski i Towarzystwa Dobroczynności. W 1916 r. były biskup saratowski, a wówczas wileński, Edward Ropp będąc wydalonym ze swojej diecezji, uczestniczył w pracach PTOW w tym mieście ${ }^{56}$.

Pojawienie się towarzystw katolickich miało w przyszłości przyczynić się do ich finansowej niezawisłości od władz państwowych i doraźnych dobroczyńców. Z przyczyn zmian ustrojowych po 1917 roku nie dano temu procesowi szans na powodzenie.

W świetle tych danych nie powinno się dziwić fragmentaryczności zachowanych wiadomości o funkcjonowaniu katolickich organizacji na terenie diecezji tyraspolskiej. Jak da się zauważyć część z nich funkcjonowała nielegalnie i z tego powodu nie prowadziła żadnej dokumentacji. Nadto zawierucha wojenna dopełniła dzieła zniszczenia.

${ }^{56}$ A. Kozyrska, Arcybiskup Edward Ropp. Życie i działalność (1851-1939), Lublin 2004, s. 40. 


\section{Устав приходского благотворительного общества при римско-католической церкви в г. Одессе ${ }^{57}$.}

\section{І Цель Общества}

$\S 1$

Общество учреждается для оказывания помощи нуждающимся прихожанам одесской римско-католической церкви.

\section{$\S 2$}

Вспомоществование оказываются: 1) выдачею продовольствия, отопления и одежды натурою; 2) единовременными периодическими денежными пособиями; 3) приисканием работы; 4) помещением стариков обоего пола в приюты и другие благотворительные учреждения; 5) помещением детей обоего пола на средства Общества в школы и сиротские дома, а если средства позволяют, в устраиваемые Обществом с разрешения правительства ремесленные школы и другие учебные заведения.

\section{II Состав Общества}

\section{$\S 3$}

Настоятель одесской приходской римско-католической церкви состоит постоянным председателем Общества. Членами Общества могут быть лица обоего пола, пожелавшие вносить в касу Общества определённый денежный взнос.

\section{$\S 4$}

Члены Общества разделяются на почётных и действительных. Почётными членами именуются те лица, кои внесут единовременно в кассу Общества не менее ста рублей, или же будут избраны в это звание общим собранием за оказанные Обществу особые услуги. Действительными членами называются вносящие ежегодно в кассу Общества не менее шести рублей. Не внесшие в течении года, до дня общего годичного собрания, этой суммы считаются выбывшими из Общества.

Примечание. Означенная сумма может быть вносима по частям не менее одного рубля.

\section{III Средства Общества}

\section{$\S 5$}

Средства Общества состоят: а) из единовременных и годичных членских взносов, б) из доходов с устраиваемых, с надлежащего разрешения и с соб-

${ }^{57}$ ГАОО ф. 35. оп. 1, д. 22476, л. 15-18. 
людением установленных правил, спектаклей, концертов, балов, публичных лекций, гуляний, в) из процентов на капитал Общества и г) из добровольных пожертвований, посредством дарения и по духовным завещанием благотворителей, движимых и недвижимых имуществ.

\section{IV Управление}

$\S 6$

Управление делами Общества возлагается на Правление. Правление, при постоянном участии в оном в качестве члена, настоятеля одесской римскокатолической церкви, состоит из девяти избранных общим собранием членов. Состав выборных членов возобновляется каждый год посредством выхода одной третьей части членов, в первые два года по жребию, а в последствии по окончании трёхгодичного срока.

\section{$\S 7$}

Для избрания членов Правления требуется абсолютное большинство голосов в общем собрании, а если такого не получит нужное число избираемых членов, то вторичная в том же заседании баллатировка решает выбор относительным большинством голосов. При получении двумя или несколькими кандидатами одинакового числа голосов, из них нужное в члены Правления число избирается по жребию. Члены Правления избираются ежегодно из среды своей Председателя, Кассира и Секретаря.

Примечание. За свои труды члены правления никакого вознаграждения не получают.

\section{$\S 8$}

В случае отсутсвия или болезни Председателя Правления, место его заступает член Правления, получивший на выборах наибольшее количество голосов.

\section{$\S 9$}

Члены Правления должны собираться в заседании не мение одного раза в месяц. Постановления Правления записываются в протокол. Для действительности постановления Правления необходимо присутствие в нём не менее трёх членов, в том числе и Председателя.

\section{$\S 10$}

Почётные члены Общества участвуют в заседаниях Правления, с правом голоса, по приглашению Председателя Правления, но они не принимают участия в избрании должностных лиц Правления. 


\section{$\S 11$}

Вопросы, подлежащие обсуждению Правления, решаются простым большинством голосов; при равенстве голосов, голос Председателя даёт перевес.

\section{$\S 12$}

Порядок делопроизводства, отчётности и администрации определяются Правлением.

\section{$\S 13$}

Правление может под свою ответственность, поручать благонадёжным членам Общества собирать всякого рода пожертвования в пользу Общества, снабдив сих членов прошнурованными книгами за печатью Общества; и испросив на это каждый раз особое разрешение от подлежащей власти.

\section{$\S 14$}

Для ознакомления с действительным положением просителей, а также для того, чтобы иметь возможность удостовериться в их личности, степени нужды и состояния здоровья, Правление приглашает нужное число лиц из членов Общества, с званием Попечителей и Попечительниц. Викарные священники одесской римско-католической церкви состоят Попечителями по своему званию.

\section{$\S 15$}

Правление распоряжается доходами Общества. Оно обязано отчислять ежегодно из доходов $20 \%$ для составления запасного капитала.

\section{$\S 16$}

Запасной капитал может быть употреблён по усмотрению общего собрания членов или на обретение недвижимой собственности в г. Одессе, или на удовлетворение других благотворительных нужд прихода.

\section{$\S 17$}

Правление представляет на утверждение годичного общего собрания отчёт о своих действиях, а также о приходе и расходе денег. Отчёты Общества, по утверждению их общим собранием, представляются в Министерство Внутренних Дел, через посредство одесского градоначальника.

\section{V Общие собрания}

\section{$\S 18$}

Общие собрания бывают обыкновенные и чрезвычайные, и созываются Председателем Общества, посредством публикаций, напечатанных в мест- 
ных газетах, три раза в течении последней недели перед днём собрания. Обыкновенные собрания созываются каждый год в декабре.

\section{$\S 19$}

Для действительности общих собраний необходимо присутствие в них не менее одной четвёртой части всего числа членов Общества. Если же в собрание означенное число членов не явится, то через две недели созывается порядком, указанным в 18 , общее собрание вторично, которое считается законным, не смотря на число присутствующих на ним членов.

\section{$\S 20$}

Общее собрание избирает, кроме членов Правления, ещё и ревизионную Комиссию из трёх членов. Комиссия эта, до дня следующего годового собрания, обязана проверить все счета, книги, кассу Общества и представить собранию протокол о ревизии, со своим заключением.

\section{$\S 21$}

Всякие изменения и дополнения настоящего устава рассматриваются собранием состоящим не менее, как из одной трети всего числа членов, и представляются на утверждение Правительства не иначе как по решению большинства двух третей голосов.

\section{$\S 22$}

В случае прекращения действий Общества, всё имущество оного поступает в собственность одесской римско-католической приходской церкви. О закрытии Общества доводится до сведения Министерства Внутренних Дел, через посредство одесского градоначальника. 


\section{WOHLTÄTIGKEIT IM RUSSISCHEN REICH AM BEISPIEL KATHOLISCHER VEREINE IN DER DIÖZESE TIRASPOL (SARATOW)}

\section{Zusammenfassung}

Der vorliegende Artikel ist einem sehr wichtigen Phänomen in der Geschichte der Kirche gewidmet, nämlich der Tätigkeit religiöser Wohltätigkeitsvereine. Im Russischen Reich entstanden solche erst verhältnismäßig spät, und zwar in der Mitte des 19. Jahrhunderts. Aber die Diözese Tiraspol bildet diesbezüglich eine Ausnahme. Diese mit dem Gedanken an deutsche Kolonisten ins Leben gerufene Diözese brauchte zu ihrer normalen Entwicklung mehr Zeit als andere Diözesen im Imperium.

Die katholische Bevölkerung bestand fast ganz aus Einwanderern und bildete ein Mosaik verschiedener Nationalitäten. Unter den Katholiken selbst bestand lange Zeit kein stärkeres Gefühl sozialer Verbundenheit, außerdem unterschieden sie sich in der Sprache. Zusätzlich war das Lebensniveau der Katholiken allzu niedrig. Deshalb entstanden in der Diözese Tiraspol erst an der Wende von 19. zum 20. Jahrhundert katholische Wohltätigkeitsvereine. Diese versammelten die Katholiken sowohl nach ihrer Nationalität als auch der geplanten Art und Weise karitativen Wirkens. Leider wurde die Entwicklung dieser Formen sozialer Aktivität mit dem Ausbruch des 1. Weltkrieges gehemmt. 